\title{
Determining Static Hyperinflation in Patients with Severe Emphysema: Relation Between Lung Function Parameters and Patient-Related Outcomes
}

\author{
Wouter W. de Weger ${ }^{1} \cdot$ Karin Klooster ${ }^{1} \cdot$ Nick H. ten Hacken ${ }^{1} \cdot$ Marlies van Dijk ${ }^{1} \cdot$ Jorine E. Hartman ${ }^{1}$. \\ Dirk-Jan Slebos ${ }^{1}$ (i)
}

Received: 23 January 2020 / Accepted: 11 June 2020 / Published online: 28 June 2020

(c) The Author(s) 2020

\begin{abstract}
Background Bronchoscopic lung volume reduction techniques are minor invasive treatment modalities for severely hyperinflated emphysema patients. The severity of static lung hyperinflation determines eligibility and success rate for these treatments. However, it is not exactly known what parameter should be used to optimally reflect hyperinflation. Commonly used parameters are residual volume (RV) and the RV/Total lung capacity (TLC) ratio. Other parameters reflecting hyperinflation are Inspiratory Capacity/TLC and forced vital capacity.

Objectives To define which of these function parameters is the most optimal reflection of hyperinflationin in relation to patient-related outcomes.

Methods In a retrospective cohort study, data from measurements during baseline visits of eight studies were pooled. Primary outcomes were RV/TLC ratio and RV as percentage of predicted (RV\%pred), both measured by bodyplethysmography, compared to the patient-related outcome variables: 6-min walk distance (6MWD), the St. George's Respiratory Questionnaire (SGRQ), and the modified Medical Research Council (mMRC).

Results Two hundred seventy-four COPD patients (mean age 59 years; $66 \%$ female), $\mathrm{FEV}_{1} 0.74 \pm 0.28 \mathrm{~L}, \mathrm{RV} 4.94 \pm 1.06 \mathrm{~L}$, $6 \mathrm{MWD}$ of $339 \pm 95 \mathrm{~m}$, were included in the analysis. Significant correlations (all $p<0.01$ ) were found between RV\%pred and 6MWD $(r=-0.358)$, SGRQ $(r=0.184)$, and mMRC $(r=0.228)$. Also, there was a significant correlation between RV/ TLC ratio and 6MWD $(r=-0.563)$, SGRQ $(r=0.289)$ and $\mathrm{mMRC}(r=0.354)$. Linear regression analyses showed that RV/ TLC ratio was a better predictor of patient outcomes than RV\%pred.

Conclusion This study demonstrates that both RV/TLC ratio and RV\%pred are relevant indicators of hyperinflation in patients with severe emphysema in relation to patient-related outcomes. RV/TLC ratio is more strongly related to the patient-related outcomes than RV\%pred.
\end{abstract}

Keywords Hyperinflation $\cdot$ Emphysema $\cdot$ Residual volume $\cdot$ Lung volume reduction $\cdot$ COPD

\section{Introduction}

Chronic obstructive pulmonary disease (COPD) is a progressive and incurable disease. This is initially reflected by a reduced forced expiratory volume in $1 \mathrm{~s}\left(\mathrm{FEV}_{1}\right)$ as well as a reduced $\mathrm{FEV}_{1}$ /forced vital capacity $(\mathrm{FVC})$ ratio $[1,2]$. Over time, this will lead to a further decrease in expiratory flow and increase in lung static hyperinflation [3]. Patients will experience limitations in rest increasing with exercise as there is an increased end-expiratory lung volume. During exercise, the time for the lungs to empty is reduced, leading to incomplete lung emptying, which results in dynamic hyperinflation. Both static and dynamic hyperinflation are
Electronic supplementary material The online version of this article (https://doi.org/10.1007/s00408-020-00368-9) contains supplementary material, which is available to authorized users.

Dirk-Jan Slebos

d.j.slebos@umcg.nl

1 Department of Pulmonary Diseases AA11, University of Groningen, University Medical Center Groningen, Hanzeplein 1, 9713 GZ Groningen, The Netherlands 
directly associated with patient-centered outcomes $[4,5]$. The level of disability experienced among patients with COPD varies widely, but can be measured using commonly used tools such as the modified Medical Research Council (mMRC) dyspnea scale, the 6-min walk test (6MWT), and the St. George's Respiratory Questionnaire (SGRQ) [6-9]. These outcomes can be improved by interventions that reduce static hyperinflation $[3,10]$ such as bronchodilators, breathing exercises, and surgical and bronchoscopic lung volume reduction (BLVR) techniques [11-13]. Especially for lung volume reduction modalities, the severity of static lung hyperinflation largely determines eligibility and success rate for these treatments $[14,15]$. However, it is not exactly known what parameter should be used to optimally reflect hyperinflation. Therefore, the there is a need to find the best objective standards to identify patients who potentially benefit most from BLVR remains.

Various lung function parameters can be used to measure hyperinflation. The most commonly used parameters to reflect static hyperinflation are the residual volume (RV) and the ratio of RV to total lung capacity (RV/TLC). Another lung function parameters reflecting hyperinflation is the ratio of the inspiratory capacity (IC) to TLC, and a low IC/TLC ratio $(<0.25)$ has been demonstrated to be prognostically unfavorable [16]. Furthermore, forced vital capacity (FVC) can be easily measured with spirometry and is negatively affected by hyperinflation [17]. The purpose of this study was to define which of these parameters is the most optimal reflection of lung hyperinflation in emphysema patients in relation to patient-related outcomes.

\section{Methods}

\section{Patients and Study Design}

This was a retrospective cohort study that included patients who were participants in eight different previous studies (performed between October 2006 and April 2016, see online Tables A1 and A2 for details) evaluating a BLVR treatment [18-25]. All study patients gave written informed consent and all studies were approved by the local ethics committee.

\section{Pulmonary Function Testing}

Pulmonary function was measured post bronchodilator (400 $\mu \mathrm{g}$ salbutamol) and according to ATS/ERS guidelines $[26,27]$. The following variables were measured during spirometry: inspiratory vital capacity (IVC), FVC, and FEV $_{1}$. Body plethysmography (Jaeger MasterScreen ${ }^{\mathrm{TM}}$ body plethysmograph (CareFusion, Germany)) was performed after the spirometry, and used to measure TLC, RV and functional residual capacity (FRC).

\section{Patient-Related Outcome Measurements}

During the baseline visit the mMRC and SGRQ were obtained. The 6MWT was performed at baseline and in accordance with ATS guidelines, and percentages of predicted were calculated from normal values $[6-9,28]$.

\section{Outcome Measures}

The primary outcome measures of interest were the correlation of RV/TLC ratio and RV as percentage of the predicted value (RV\%pred) to the mMRC, SGRQ, and 6MWT. Other outcome measures were correlations of other potential measurements of hyperinflation: FVC\% pred, IC/TLC ratio to the mMRC, SGRQ, and 6MWT.

\section{Statistical Analysis}

Correlation coefficients were calculated to establish whether there was a correlation between pulmonary function variables and patient-related outcomes. When data were normally distributed, Pearson correlation was used. Spearman correlation was used when data were not normally distributed. Linear regression analysis was performed to evaluate the independent predictors of 6MWD and SGRQ and we included the primary outcome measures only. Variables with a univariate association with a p-value of $<0.20$ were considered to be used in a linear regression model (method enter). The linear regression model was adjusted for age, gender, height, and weight. Highly correlating variables (correlation coefficient $>0.70$ ) were not included in the model, because of multicollinearity. RV/TLC ratio, RV\%pred, and FVC\% pred were divided in categories and then used in the linear regression analyses as follows: RV/TLC $<50 \%$, $50-55 \%, 55-58 \%, 58-62 \%, 62-65 \%, 65-70 \%$, and $>70 \%$; RV\% pred $<175 \%, 175-200 \%, 200-225 \%, 225-250 \%$, and $>250 \%$; FVC $\%$ pred $<60 \%, 60-70 \%, 70-80 \%, 80-90 \%$, $90-100 \%$, and $>100 \%$. A $p$-value of $<0.05$ was considered statistically significant. IBM SPSS Statistics version 23 (IBM, NY, USA) was used for all analyses.

\section{Results}

A total of 275 patients with severe COPD were included in this study, with one patient being excluded from further analysis because of missing body plethysmograph measurements. Thus, a total of 274 were used for the final analyses (See Table 1 for patient characteristics). 
Table 1 Patient characteristics $(N=274)$

\begin{tabular}{|c|c|}
\hline \multicolumn{2}{|l|}{ Demographics } \\
\hline Male/female & $94 / 180$ \\
\hline Age (years) & $59 \pm 8$ \\
\hline Body Mass Index $\left(\mathrm{kg} / \mathrm{m}^{2}\right)$ & $23.7 \pm 3.6$ \\
\hline Pack years (1/year) & $37 \pm 17$ \\
\hline \multicolumn{2}{|l|}{ Pulmonary function } \\
\hline FVC (Liter) & $2.57 \pm 0.83$ \\
\hline FVC ( $\%$ of predicted value) & $76.07 \pm 17.45$ \\
\hline $\mathrm{FEV}_{1}($ Liter $)$ & $0.74 \pm 0.28$ \\
\hline $\mathrm{FEV}_{1}(\%$ of predicted value $)$ & $26.99 \pm 8.59$ \\
\hline $\mathrm{FEV}_{1} / \mathrm{FVC}(\%)$ & $29.39 \pm 6.93$ \\
\hline TLC (Liter) & $7.84 \pm 1.41$ \\
\hline Predicted TLC (Liter) & $5.77 \pm 1.06$ \\
\hline VC (Liter) & $2.88 \pm 0.87$ \\
\hline FRC (Liter) & $6.08 \pm 1.23$ \\
\hline RV (Liter) & $4.94 \pm 1.06$ \\
\hline IC (Liter) & $1.76 \pm 0.59$ \\
\hline $\operatorname{Raw}(\mathrm{kPa} /$ Liter/second $)(N=245)$ & $0.74 \pm 0.28$ \\
\hline SGaw, $1 /\left(\mathrm{kPa}^{*}\right.$ second $)(N=213)$ & $0.26 \pm 0.12$ \\
\hline Ratio of RV to TLC (\%) & $63.12 \pm 8.06$ \\
\hline Ratio of RV to TLC predicted (\%) & $86.62 \pm 16.05$ \\
\hline Ratio of IC to TLC (\%) & $22.51 \pm 6.41$ \\
\hline Ratio of FVC to VC (\%) & $88.16 \pm 8.23$ \\
\hline Ratio of FRC to TLC (\%) & $77.49 \pm 6.41$ \\
\hline \multicolumn{2}{|l|}{ Patient related outcomes } \\
\hline St. George's respiratory questionnaire, total score $(N=269)$ & $61.2 \pm 12.3$ \\
\hline 6 -min walk distance $(N=273)$, meter & $339 \pm 95$ \\
\hline$\%$ of predicted value & $61 \pm 17$ \\
\hline Modified medical research council scale, grade $(N=265)$ & $2.9 \pm 0.7$ \\
\hline
\end{tabular}

Results are presented as mean \pm standard deviation. Other parameters are presented as numbers

$F V C$ forced vital capacity, $F E V_{l}$ forced expiratory volume in $1 \mathrm{~s}, T L C$ total lung capacity, $V C$ vital capacity, $F R C$ forced residual capacity, $R V$ residual volume, $I C$ inspiratory capacity, Raw airway resistance, SGaw 1/airway resistance
Significant correlations were found between both RV/ TLC ratio and 6MWD $(r=-0.563, p<0.001)$ and between $\mathrm{RV} \%$ pred and 6MWD $(r=-0.358, p<0.001)$. We found lower, but still statistically significant correlations of RV/ TLC ratio and RV\%pred with SGRQ (Fig. 1a-f) (See Table 2 for all correlations).

Linear regression analyses showed that RV/TLC ratio, $\mathrm{RV} \%$ pred, and $\mathrm{FVC} \%$ pred are independent predictors of 6MWD (online supplement, Tables 3A-C). The model using RV/TLC ratio explained most of the variation in 6MWD $\left(R^{2}=0.476\right)$. When RV/TLC ratio increases by one percent, a patient walks approximately $4.8 \mathrm{~m}$ fewer $(b=-4.812)$. Linear regression analyses of SGRQ showed that the primary outcome measures (RV/TLC ratio, RV\%pred) and FVC\%pred are not independent predictors of SGRQ (online supplement, Tables A3A-C). We also performed linear regression analyses with the primary outcome measures divided into categories. We found significant differences between the RV/TLC ratio categories. This model explained $47.3 \%$ of the variation in 6MWD (online supplement, Table A4A). Using this model, a hypothetical patient with a RV/TLC ratio of $>70 \%$ walked approximately $116 \mathrm{~m}$ less during a 6MWT compared to patients with a RV/TLC ratio $<50 \%$. The model with $\mathrm{RV} \%$ pred can be used to explain $41.4 \%$ of the variation in $6 \mathrm{MWD}$ outcome. When using RV\% pred $>250 \%$ as reference value, all other categories were significantly different compared to this reference category. The model including FVC\% $\%$ pred (Table A4C) explained $46.7 \%$ of the variation in 6MWD outcome. In addition, linear regression analyses of SGRQ showed no significant differences between several categories of RV/TLC ratio, RV\%pred, and FVC\%pred (online supplement, Tables A5A-C). 

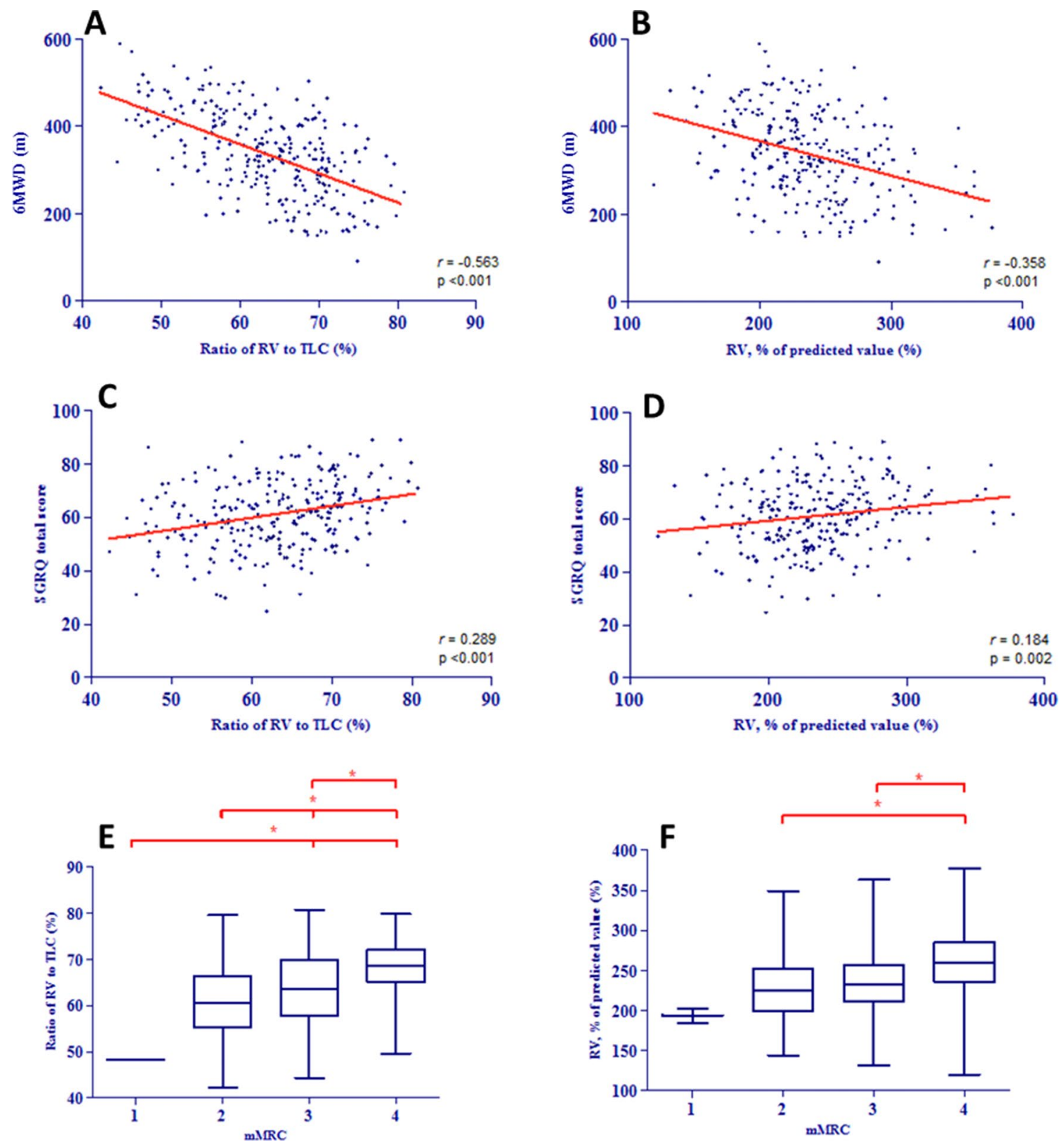

Fig. 1 a scatterplot of 6-min walk test (6MWT) and residual volume/ total lung capacity ratio (RV/TLC); b scatterplot of 6MWT and RV \% of predicted; c scatterplot of the Saint George's Respiratory Questionnaire (SGRQ) and RV/TLC ratio; $\mathbf{d}$ scatterplot of SGRQ and RV \% of

\section{Discussion}

The results of this study show that RV/TLC ratio and $\mathrm{RV} \%$ pred both provide relevant information about the impact of hyperinflation on the patients quality of life and exercise tolerance, with RV/TLC ratio being the best predictor of the variation in outcomes.

Interestingly, the correlation of RV/TLC to patient-related outcomes is stronger than the correlation between RV\%pred and patient-related outcomes. A possible explanation is that

predicted; e boxplot of the modified medical Research Counsel dyspnea scale (mMRC) and RV/TLC ratio; $\mathbf{f}$ boxplot of mMRC and RV \% of predicted. *Indicates $p<0.05$

$\mathrm{RV} / \mathrm{TLC}$ is calculated by dividing the actual measured RV in liters by the patients' own actual measured TLC in liters, thus not being limited by predicted values based on length, age, and gender. In other words, RV\%pred is a general parameter, with potential bias, making it a little less suitable for accurate individual measurement of hyperinflation. Our results are in line with an earlier study in surgical lung volume reduction patients, which reported a strong correlation between RV/TLC ratio and the reduction in $\mathrm{FEV}_{1}$ [29] (Table 3). 
Table 2 Correlations overview

\begin{tabular}{|c|c|c|c|c|c|c|}
\hline Variable & $\mathrm{mMRC}$ & $p$-value & SGRQ & $p$-value & 6MWD & $p$-value \\
\hline Pack years (years) & 0.008 & 0.893 & 0.051 & 0.404 & -0.008 & 0.897 \\
\hline Age (years) & $0.113^{*}$ & $0.067 *$ & $0.079 *$ & $0.198 *$ & -0.141 & 0.019 \\
\hline Height (centimeter) & $-0.103^{*}$ & $0.093 *$ & $-0.090 *$ & $0.142 *$ & 0.195 & 0.001 \\
\hline Weight (kg) & -0.020 & 0.742 & -0.030 & 0.623 & 0.047 & 0.436 \\
\hline Body Mass Index $\left(\mathrm{kg} / \mathrm{m}^{2}\right)$ & 0.050 & 0.419 & 0.026 & 0.669 & $-0.078 *$ & $0.200 *$ \\
\hline $\operatorname{IVC}(\mathrm{L})$ & 0.307 & $<0.001$ & -0.246 & $<0.001$ & 0.508 & $<0.001$ \\
\hline IVC ( $\%$ of predicted value) & -0.271 & $<0.001$ & -0.227 & $<0.001$ & 0.458 & $<0.001$ \\
\hline $\mathrm{VC}(\mathrm{L})$ & -0.302 & $<0.001$ & -0.257 & $<0.001$ & 0.464 & $<0.001$ \\
\hline FVC (L) & -0.294 & $<0.001$ & -0.244 & $<0.001$ & 0.484 & $<0.001$ \\
\hline FVC ( $\%$ of predicted value) & -0.250 & $<0.001$ & -0.218 & $<0.001$ & 0.416 & $<0.001$ \\
\hline $\mathrm{FEV}_{1}(\mathrm{~L})$ & -0.328 & $<0.001$ & -0.199 & 0.001 & 0.542 & $<0.001$ \\
\hline $\mathrm{FEV}_{1}(\%$ of predicted value $)$ & -0.272 & $<0.001$ & -0.141 & 0.021 & 0.466 & $<0.001$ \\
\hline $\operatorname{TLC}(\mathrm{L})$ & -0.059 & 0.335 & -0.048 & 0.434 & $0.116^{*}$ & $0.055^{*}$ \\
\hline TLC ( $\%$ of predicted value) & $0.098^{*}$ & $0.110^{*}$ & 0.058 & 0.346 & -0.127 & $\mathbf{0 . 0 3 7}$ \\
\hline RV (L) & 0.169 & 0.006 & 0.134 & 0.028 & -0.254 & $<0.001$ \\
\hline RV (\% of predicted value) & 0.228 & $<0.001$ & 0.184 & 0.002 & $-\mathbf{0 . 3 5 8}$ & $<0.001$ \\
\hline FRC (L) & 0.071 & 0.248 & 0.050 & 0.414 & -0.129 & $\mathbf{0 . 0 3 3}$ \\
\hline FRC ( $\%$ of predicted value) & 0.206 & 0.001 & 0.145 & 0.017 & -0.335 & $<0.001$ \\
\hline Raw (kPa/Liter/second) & 0.329 & $<0.001$ & 0.317 & $<0.001$ & -0.489 & $<0.001$ \\
\hline Raw (\% of predicted value) & 0.290 & $<0.001$ & 0.301 & $<0.001$ & -0.494 & $<0.001$ \\
\hline SGaw, 1/(kPa*second) & -0.273 & $<0.001$ & -0.236 & 0.001 & 0.512 & $<0.001$ \\
\hline SGaw (\% of predicted value) & -0.289 & $<0.001$ & -0.260 & $<0.001$ & 0.553 & $<0.001$ \\
\hline $\mathrm{IC}(\mathrm{L})$ & -0.302 & $<0.001$ & -0.227 & $<0.001$ & 0.529 & $<0.001$ \\
\hline RV/TLC (\%) & 0.354 & $<0.001$ & 0.289 & $<0.001$ & 0.563 & $<0.001$ \\
\hline RV/TLCpredicted (\%) & 0.298 & $<0.001$ & 0.228 & $<0.001$ & 0.452 & $<0.001$ \\
\hline Ratio of FVC to VC (\%) & -0.010 & 0.877 & -0.043 & 0.486 & 0.005 & 0.939 \\
\hline Ratio of IC to TLC (\%) & $-\mathbf{0 . 3 0 7}$ & $<0.001$ & -0.227 & $<0.001$ & 0.550 & $<0.001$ \\
\hline Ratio of FRC to TLC (\%) & 0.305 & $<0.001$ & 0.244 & $<0.001$ & -0.547 & $<0.001$ \\
\hline Ratio of $\mathrm{FEV}_{1}$ to FVC (\%) & -0.162 & 0.008 & -0.004 & 0.953 & 0.245 & $<0.001$ \\
\hline SGRQ (points) & 0.518 & $<0.001$ & - & - & -0.368 & $<0.001$ \\
\hline 6MWD (meter) & -0.512 & $<0.001$ & -0.368 & $<0.001$ & - & - \\
\hline mMRC (points) & - & - & 0.518 & $<0.001$ & -0.512 & $<0.001$ \\
\hline
\end{tabular}

$I V C$ inspiratory vital capacity, $F V C$ forced vital capacity, $F E V_{l}$ forced expiratory volume in $1 \mathrm{~s}$, $T L C$ total lung capacity, $R V$ residual volume, $F R C$ forced residual capacity, Raw airway resistance, SGaw 1/airway resistance, IC inspiratory capacity, $m M R C$ modified medical research council scale, SGRQ St. George's Respiratory Questionnaire, 6MWD 6-min walk distance

Significant values $(p<0.05)$ were depicted in bold. $* 0.05 \geq p \leq 0.20$

The results of this study showed that the primary outcome variables (RV/TLC ratio, $\mathrm{RV} \%$ pred) and $\mathrm{FVC} \%$ pred correlated best with 6MWD and SGRQ. Many factors are known to contribute to the 6MWD in this patient group. Previous studies showed that 6MWD correlated to multiple pulmonary function variables such as RV/TLC ratio, $\mathrm{FEV}_{1}$, $\mathrm{FEV}_{1}$ as percentage of predicted value, $\mathrm{FVC}$, and $\mathrm{FEV}_{1} /$ FVC ratio, but also age, weight, gender, and height, and even SGRQ and mMRC explain a great variety in 6MWD $[30,31]$. Even a learning curve could also be an influencing factor: the more often someone performs the test, the better this person understands in which manner the best result can be achieved [28, 32]. Contrary to the 6MWD, there are just minimal correlations between the pulmonary function test values and SGRQ. Furthermore, the independent predictors that were significant for 6MWD were not significant for the SGRQ. This is somewhat surprising, since the previous studies indicate a quite fair clinical significance of the SGRQ to other clinical outcomes [7, 8]. A possible explanation might be that this questionnaire is a more subjective measurement than the 6MWT. Furthermore, it may be that patients with the most advanced COPD (such as our now evaluated very severe emphysema patients) were not included in the initial validation studies of the SGRQ. This is also reflected by the fact that we recently showed that the minimal clinical important difference for the SGRQ total score for this patient 
Table 3 Linear model of predictors of 6MWD (meter)

\begin{tabular}{|c|c|c|c|c|}
\hline Variable & $\mathrm{b}$ & SE B & $\beta$ & $p$-value \\
\hline \multicolumn{5}{|l|}{ A } \\
\hline RV/TLC & -4.812 & 0.621 & -0.404 & $<0.001$ \\
\hline Ratio of $\mathrm{FEV}_{1}$ to FVC & 2.584 & 0.666 & 0.187 & $<0.001$ \\
\hline Age & -0.509 & 0.602 & -0.043 & 0.398 \\
\hline Gender & 1.822 & 13.913 & 0.009 & 0.896 \\
\hline Height & 1.925 & 0.792 & 0.174 & 0.016 \\
\hline Weight & -1.219 & 0.424 & -0.159 & 0.004 \\
\hline $\mathrm{mMRC}$ & -36.584 & 7.545 & -0.272 & $<0.001$ \\
\hline SGRQ & -0.783 & 0.420 & -0.101 & 0.063 \\
\hline \multicolumn{5}{|l|}{ B } \\
\hline RV_perc_pred & -0.634 & 0.124 & -0.287 & $<0.001$ \\
\hline $\mathrm{FEV}_{1} / \mathrm{FVC}$ & 2.036 & 0.736 & 0.147 & 0.006 \\
\hline Age & -2.242 & 0.638 & -0.189 & 0.001 \\
\hline Gender & -4.087 & 14.715 & -0.020 & 0.781 \\
\hline Height & 2.719 & 0.851 & 0.246 & 0.002 \\
\hline Weight & -1.139 & 0.450 & -0.148 & 0.012 \\
\hline mMRC & -42.776 & 7.898 & -0.318 & $<0.001$ \\
\hline SGRQ & -0.925 & 0.445 & -0.119 & 0.038 \\
\hline \multicolumn{5}{|l|}{$\mathrm{C}$} \\
\hline FVC_perc_pred & 1.946 & 0.262 & 0.358 & $<0.001$ \\
\hline $\mathrm{FEV}_{1} / \mathrm{FVC}$ & 4.012 & 0.677 & 0.290 & $<0.001$ \\
\hline Age & -1.913 & 0.595 & -0.161 & 0.001 \\
\hline Gender & -22.788 & 13.836 & -0.113 & 0.101 \\
\hline Height & 2.124 & 0.799 & 0.192 & 0.008 \\
\hline Weight & -0.996 & 0.425 & -0.130 & 0.020 \\
\hline mMRC & -35.882 & 7.636 & -0.266 & $<0.001$ \\
\hline SGRQ & -1.009 & 0.420 & -0.130 & 0.017 \\
\hline
\end{tabular}

(a) $R^{2}=0.476$; (b) $R^{2}=0.413$; (c) $R^{2}=0.467$

$R V$ residual volume, $T L C$ total lung capacity, $R V \_T L C$ _ratio ratio of $\mathrm{RV}$ to TLC, $R V \_$perc_pred residual volume, percentage of predicted value, FVC_perc_pred forced vital capacity, percentage of predicted value, $F E V_{l}$ forced expiratory volume in $1 \mathrm{~s}, F V C$ forced vital capacity, $6 M W D$ 6-min walk distance, $m M R C$ modified Medical Research Council dyspnea scale, $S G R Q$ St. George's Respiratory Questionnaire Significant values $(p<0.05)$ were depicted in bold

group is a change of 7 points 6 months after intervention, whereas the validation literature showed a difference of only 4 points in a patient population with milder $\operatorname{COPD}[8,33]$.

Looking at the mMRC, it might be concluded that this parameter was not as useful as we expected. Considering this is a categorical variable with a zero to four scale, it is perhaps less sensitive to detect feelings of breathlessness related to the level of hyperinflation. Another explanation for a low sensitivity might be that the mMRC is not a composite measure, but only measures the general dyspnea sensation. The results of this study are in line with an earlier study that demonstrated a discrepancy when comparing several scores from mMRC with COPD assessment test (CAT; health status) [34]. On the other hand, it can be noticed that in every linear regression model of the predictors of 6MWD and SGRQ, mMRC is a sensitive predictor. Therefore, the exact role of mMRC when determining hyperinflation remains unclear.

Next to RV/TLC ratio, FVC is also of great importance to display the health status after a procedure. A relative simple explanation can be that after lung volume reduction, the RV/TLC ratio improves and so does VC, and thus FVC. Previous research showed improved FVC is an important predictor of an improved $\mathrm{FEV}_{1}$ [35]. Also in our data, a high correlation was found between FVC and 6MWD $(r=0.484, p<0.001)$, as well as significant, but slightly weaker correlations between FVC and SGRQ or mMRC. So FVC might be a relevant variable when trying to select patients who benefit most from BLVR. The potential advantage of using FVC as a "screening" tool is the fact that it can be derived from a simple spirometry (flow/volume measurement), making it a cheap and easy to use tool.

The FVC/VC ratio does not correlate significantly with any patient-related outcome variable (Table 2). This can be explained by the fact that both parameters are strongly associated, and thus leverage each other. The impact of $\mathrm{FEV}_{1} /$ FVC ratio is not strongly correlated with patient-related outcomes as well. Generally, this ratio is used to indicate the amount of airflow limitation [36]. Also, this study showed a weak but significant correlation between this ratio and 6MWD $(r=-0.245, p<0.001)$. Furthermore, the correlation between $\mathrm{FEV}_{1} / \mathrm{FVC}$ ratio and SGRQ is not significant at all $(r=-0.004, p=0.953)$. A conclusion could be that $\mathrm{FEV}_{1} / \mathrm{FVC}$ ratio does not correspond to the clinical magnitude of hyperinflation and is therefore less suitable for the goal of this study.

Another variable we looked at was IC/TLC ratio. In our study population both functional residual capacity and TLC are increased. As a result, IC is decreased and a situation arises which is referred to as hyperinflation. IC/TLC ratio correlates significantly with all patient outcome variables, yet comparable with RV/TLC ratio. Therefore, it might be useful to keep this ratio in mind when trying to select the best patients for BLVR. The small downside of using IC/ TLC, is that a separate IC maneuver needs to be performed to capture this data, while with measuring and calculating TLC, RV is readily available.

The goal of this study was to determine which of our selected parameters is the best reflection of hyperinflation in relation to patient-related outcomes. Much research has been conducted to discover the physiological concepts behind lung volume reduction, with patients having static hyperinflation, and reducing this by many different interventions being the main driver of response [37]. This study is one of the first to specify the best measure of static hyperinflation in this patient population 
In conclusion, we showed that both RV/TLC ratio and $\mathrm{RV} \%$ pred are relevant indicators of hyperinflation in relation to patient-related outcomes in patients with severe emphysema, with the RV/TLC ratio being the best predictor of the variation in baseline 6MWD. Further research is necessary to even more accurately determine other measures of hyperinflation that correlate with limitations experienced by patients.

\section{Compliance with Ethical Standards}

Conflict of interest Wouter W.de Weger, Karin KloosterNick, H. ten Hacken, Marlies van Dijk, Jorine E. Hartman, and Dirk-Jan Slebos declare no conflicts of interest.

Open Access This article is licensed under a Creative Commons Attribution 4.0 International License, which permits use, sharing, adaptation, distribution and reproduction in any medium or format, as long as you give appropriate credit to the original author(s) and the source, provide a link to the Creative Commons licence, and indicate if changes were made. The images or other third party material in this article are included in the article's Creative Commons licence, unless indicated otherwise in a credit line to the material. If material is not included in the article's Creative Commons licence and your intended use is not permitted by statutory regulation or exceeds the permitted use, you will need to obtain permission directly from the copyright holder. To view a copy of this licence, visit http://creativecommons.org/licenses/by/4.0/.

\section{References}

1. McDonough JE, Yuan R, Suzuki M, Seyednejad N, Elliott WM, Sanchez PG, Wright AC, Gefter WB, Litzky L, Coxson HO, Pare PD, Sin DD, Pierce RA, Woods JC, McWilliams AM, Mayo JR, Lam SC, Cooper JD, Hogg JC (2011) Small-airway obstruction and emphysema in chronic obstructive pulmonary disease. N Engl J Med 365:1567-1575. https://doi.org/10.1056/NEJMoa1 106955

2. Hogg JC, Chu F, Utokaparch S, Woods R, Elliott WM, Buzatu L, Cherniack RM, Rogers RM, Sciurba FC, Coxson HO, Pare PD (2004) The nature of small-airway obstruction in chronic obstructive pulmonary disease. N Engl J Med 350:2645-2653. https://doi. org/10.1056/NEJMoa032158

3. Ferguson GT (2006) Why does the lung hyperinflate? Proc Am Thorac Soc 3:176-179. https://doi.org/10.1513/pats.20050 8-094DO

4. Fessler HE, Scharf SM, Ingenito EP, McKenna RJ Jr, Sharafkhaneh A (2008) Physiologic basis for improved pulmonary function after lung volume reduction. Proc Am Thorac Soc 5:416-420. https://doi.org/10.1164/ajrccm.157.3.9608004

5. Klooster K, ten Hacken NH, Hartman JE, Sciurba FC, Kerstjens HA, Slebos DJ (2015) Determining the role of dynamic hyperinflation in patients with severe chronic obstructive pulmonary disease. Respiration 90:306-313. https://doi.org/10.1159/00043 9056

6. TS Committee on Proficiency Standards for Clinical Pulmonary Function Laboratories (2002) ATS statement: guidelines for the six-minute walk test. Am J Respir Crit Care Med 166:111-117. https://doi.org/10.1164/ajrccm.166.1.at1102

7. Jones PW, Quirk FH, Baveystock CM, Littlejohns P (1992) A selfcomplete measure of health status for chronic airflow limitation.
The St. George's Respiratory Questionnaire. Am Rev Respir Dis 145:1321-1327. https://doi.org/10.1164/ajrccm/145.6.1321

8. Jones PW (2005) St. George's Respiratory Questionnaire: MCID. COPD 2:75-79. https://doi.org/10.1081/copd-200050513

9. Bestall JC, Paul EA, Garrod R, Garnham R, Jones PW, Wedzicha JA (1999) Usefulness of the Medical Research Council (MRC) dyspnoea scale as a measure of disability in patients with chronic obstructive pulmonary disease. Thorax 54:581-586. https://doi. org/10.1136/thx.54.7.581

10. Cooper CB (2006) The connection between chronic obstructive pulmonary disease symptoms and hyperinflation and its impact on exercise and function. Am J Med 119:21-31. https://doi. org/10.1016/j.amjmed.2006.08.004

11. Mineshita M, Slebos DJ (2014) Bronchoscopic interventions for chronic obstructive pulmonary disease. Respirology 19:11261137. https://doi.org/10.1111/resp.12362

12. Ingenito EP, Wood DE, Utz JP (2008) Bronchoscopic lung volume reduction in severe emphysema. Proc Am Thorac Soc 5:454-460. https://doi.org/10.1513/pats.200707-085ET

13. Rossi A, Aisanov Z, Avdeev S, Di Maria G, Donner CF, Izquierdo JL, Roche N, Similowski T, Watz H, Worth H, Miravitlles M (2015) Mechanisms, assessment and therapeutic implications of lung hyperinflation in COPD. Respir Med 109:785-802. https ://doi.org/10.1016/j.rmed.2015.03.010

14. Fishman A, Martinez F, Naunheim K, Piantadosi S, Wise R, Ries A, Weinmann G, Wood DE, National Emphysema Treatment Trial Research Group (2003) A randomized trial comparing lung-volume-reduction surgery with medical therapy for severe emphysema. N Engl J Med 348:2059-2073. https://doi. org/10.1056/NEJMoa030287

15. Herth FJF, Slebos DJ, Criner GJ, Valipour A, Sciurba F, Shah PL (2019) Endoscopic lung volume reduction: an expert panel recommendation — update 2019. Respiration 97:548-557. https ://doi.org/10.1159/000496122

16. O'Donnell DE, Laveneziana P (2006) Physiology and consequences of lung hyperinflation in COPD. Eur Respir Rev 15:6167. https://doi.org/10.1183/09059180.00010002

17. Quanjer PH, Ruppel GL, Langhammer A, Krishna A, Mertens F, Johannessen A, Menezes AMB, Wehrmeister FC, Perez-Padilla R, Swanney MP, Tan WC, Bourbeau J (2017) Bronchodilator response in FVC is larger and more relevant than in FEV1 in severe airflow obstruction. Chest 151:1088-1098. https://doi. org/10.1016/j.chest.2016.12.017

18. Shah PL, Slebos DJ, Cardoso PF, Cetti E, Voelker K, Levine B, Russell ME, Goldin J, Brown M, Cooper JD, Sybrecht GW, EASE trial study group (2011) Bronchoscopic lung-volume reduction with Exhale airway stents for emphysema (EASE trial): randomised, sham-controlled, multicentre trial. Lancet 378:997-1005. https://doi.org/10.1016/S0140-6736(11)61050 $-7$

19. Herth FJ, Eberhardt R, Gompelmann D, Ficker JH, Wagner M, Ek L, Schmidt B, Slebos DJ (2013) Radiological and clinical outcomes of using chartis to plan endobronchial valve treatment. Eur Respir J 41:302-308. https://doi.org/10.1183/09031936.00015312

20. Klooster K, ten Hacken NH, Hartman JE, Kerstjens HA, van Rikxoort EM, Slebos DJ (2015) Endobronchial valves for emphysema without interlobar collateral ventilation. N Engl J Med 373:23252335. https://doi.org/10.1056/NEJMoa1507807

21. Valipour A, Slebos DJ, Herth F, Darwiche K, Wagner M, Ficker JH, Petermann C, Hubner RH, Stanzel F, Eberhardt R, IMPACT Study Team (2016) Endobronchial valve therapy in patients with homogeneous emphysema. Results from the IMPACT Study. Am J Respir Crit Care Med 194:1073-1082. https://doi.org/10.1164/ rccm.201607-1383OC

22. Slebos DJ, Klooster K, Ernst A, Herth FJF, Kerstjens HAM (2012) Bronchoscopic lung volume reduction coil treatment of patients 
with severe heterogeneous emphysema. Chest 142:574-582. https ://doi.org/10.1378/chest.11-0730

23. Deslee G, Klooster K, Hetzel M, Stanzel F, Kessler R, Marquette CH, Witt C, Blaas S, Gesierich W, Herth FJ, Hetzel J, van Rikxoort EM, Slebos DJ (2014) Lung volume reduction coil treatment for patients with severe emphysema: a European multicentre trial. Thorax 69:980-986. https://doi.org/10.1136/thoraxjnl-2014205221

24. Klooster K, Ten Hacken NH, Franz I, Kerstjens HA, van Rikxoort EM, Slebos DJ (2014) Lung volume reduction coil treatment in chronic obstructive pulmonary disease patients with homogeneous emphysema: a prospective feasibility trial. Respiration 88:116125. https://doi.org/10.1159/000362522

25. Sciurba FC, Criner GJ, Strange C, Shah PL, Michaud G, Connolly TA, Deslee G, Tillis WP, Delage A, Marquette CH, Krishna G, Kalhan R, Ferguson JS, Jantz M, Maldonado F, McKenna R, Majid A, Rai N, Gay S, Dransfield MT, Angel L, Maxfield R, Herth FJ, Wahidi MM, Mehta A, Slebos DJ, RENEW Study Research Group (2016) Effect of endobronchial coils vs usual care on exercise tolerance in patients with severe emphysema: the RENEW randomized clinical trial. JAMA 315:2178-2189. https ://doi.org/10.1001/jama.2016.6261

26. Miller MR, Crapo R, Hankinson J, Brusasco V, Burgos F, Casaburi R, Coates A, Enright P, van der Grinten CP, Gustafsson P, Jensen R, Johnson DC, MacIntyre N, McKay R, Navajas D, Pedersen OF, Pellegrino R, Viegi G, Wanger J, ATS/ERS Task Force (2005) General considerations for lung function testing. Eur Respir J 26:153-161. https://doi.org/10.1183/09031936.05.00034 505

27. Miller MR, Hankinson J, Brusasco V, Burgos F, Casaburi R, Coates A, Crapo R, Enright P, van der Grinten CP, Gustafsson P, Jensen R, Johnson DC, MacIntyre N, McKay R, Navajas D, Pedersen OF, Pellegrino R, Viegi G, Wanger J, ATS/ERS Task Force (2005) Standardisation of spirometry. Eur Respir J 26:319-338. https://doi.org/10.1183/09031936.05.00034805

28. Troosters T, Gosselink R, Decramer M (1999) Six minute walking distance in healthy elderly subjects. Eur Respir J 14:270-274. https://doi.org/10.1034/j.1399-3003.1999.14b06.x

29. Fessler HE, Permutt S (1998) Lung volume reduction surgery and airflow limitation. Am J Respir Crit Care Med 157:715-722. https ://doi.org/10.1164/ajrccm.157.3.9608004

30. Chen H, Liang BM, Tang YJ, Xu ZB, Wang K, Yi Q, Ou XM, Feng YL (2012) Relationship between 6-minute walk test and pulmonary function test in stable chronic obstructive pulmonary disease with different severities. Chin Med J (Engl) 125:3053-3058

31. Agrawal MB, Awad NT (2015) Correlation between six minute walk test and spirometry in chronic pulmonary disease. J Clin Diagn Res 9:OC01-OC4. https://doi.org/10.7860/ JCDR/2015/13181.6311

32. Enright PL, Sherrill DL (1998) Reference equations for the six-minute walk in healthy adults. Am J Respir Crit Care Med 158:1384-1387. https://doi.org/10.1164/ajrccm.158.5.9710086

33. Welling JB, Hartman JE, Ten Hacken NH, Klooster K, Slebos DJ (2015) The minimal important difference for the St George's Respiratory Questionnaire in patients with severe COPD. Eur Respir J 46:1598-1604. https://doi.org/10.1183/13993003.00535-2015

34. Rhee CK, Kim JW, Hwang YI, Lee JH, Jung KS, Lee MG, Yoo KH, Lee SH, Shin KC, Yoon HK (2015) Discrepancies between modified Medical research council dyspnea score and COPD assessment test score in patients with COPD. Int J Chron Obstruct Pulmon Dis 10:1623-1631. https://doi.org/10.2147/COPD.S8714 7

35. Fessler HE, Scharf SM, Permutt S (2002) Improvement in spirometry following lung volume reduction surgery: application of a physiologic model. Am J Respir Crit Care Med 165:34-40. https ://doi.org/10.1513/pats.200708-117ET

36. Singh D, Agusti A, Anzueto A, Barnes PJ, Bourbeau J, Celli BR, Criner GJ, Frith P, Halpin DMG, Han M, Lopez Varela MV, Martinez F, Montes de Oca M, Papi A, Pavord ID, Roche N, Sin DD, Stockley R, Vestbo J, Wedzicha JA, Vogelmeier C (2019) Global strategy for the diagnosis, management, and prevention of chronic obstructive lung disease: the GOLD science committee report 2019. Eur Respir J. https://doi.org/10.1183/13993003.00164-2019

37. van Geffen WH, Slebos DJ, Herth FJ, Kemp SV, Weder W, Shah PL (2019) Surgical and endoscopic interventions that reduce lung volume for emphysema: a systemic review and meta-analysis. Lancet Respir Med 7:313-324. https://doi.org/10.1016/S2213 $-2600(18) 30431-4$

Publisher's Note Springer Nature remains neutral with regard to jurisdictional claims in published maps and institutional affiliations. 